\title{
Trendy w stosowaniu rozwiązań technicznych wpływających na zużycie energii w budynkach mieszkalnych
}

\author{
Kajetan Sadowski \\ e-mail: kajetan.sadowski@pwr.edu.pl \\ Zakład konstrukcji i budownictwa ogólnego, Wydziat Architektury Politechniki Wroctawskiej \\ Assistant professor Faculty of Architecture, Wroclaw University of Technology
}

53-517 Wrocław, ul. Prusa 53/55

\begin{abstract}
Streszczenie: Certyfikacja energetyczna, wprowadzona w 2009 r. umożliwia zainteresowanym osobom lub instytucjom analizowanie danych opracowanych podczas przygotowywania świadectw charakterystyki energetycznej lub projektowanych charakterystyk energetycznych budynków. Dzięki analizom porównawczym, stosując określone w zależności od potrzeb kryteria, można opisać występujące w wykonawstwie i projektowaniu trendy.

Autor wykonał szereg wybrane analiz koncentrujących się na budownictwie mieszkaniowym z podziałem na sektor budynków jednorodzinnych oraz wielorodzinnych. Uzyskane wyniki wskazują na istniejące i oczekiwane trendy związane z ograniczeniem zużycia paliw kopalnych ale także uwidaczniają ich zbyt powolne tempo a w niektórych przypadkach nawet brak zmian. Wyprowadzone wnioski wskazują na przyczyny określonego tempa zmian umożliwiając zainteresowanym podmiotom na podejmowanie działań podtrzymujących określone tendencje bądź je inicjujących.

W ramach niniejszej pracy autor przeanalizował wybrane wskaźniki na podstawie wykonanych przez siebie w latach 2014-2017 r. 168 certyfikatów energetycznych budynków mieszkalnych.
\end{abstract}

Słowa kluczowe: budownictwo energooszczędne, certyfikacja energetyczna, ekologia, zrównoważony rozwój.

\section{Wstęp}

Od 2009 roku funkcjonują w obrocie prawnym oraz w praktyce inżynierskiej w Polsce dokumenty nazywane projektowaną charakterystyką energetyczną budynku oraz świadectwem charakterystyki energetycznej budynku. Dokumenty te są jednym z elementów implementacji prawa europejskiego wyrażonego za pomocą unijnej dyrektywy nr 2002/91/WE, następnie aktualizowanej w kolejnych latach. Dzięki zgromadzonym na ich podstawie danym możliwa jest obserwacja trendów w budownictwie związanych ze zmniejszaniem zapotrzebowania na energię niezbędną do utrzymania budynków. Trendy te częściowo mogą wynikać ze zmieniających się wymagań w zastosowaniu określonych jakościowo rozwiązań technicznych lub być odpowiedzią na tendencje rynkowe.

Autor podjął próbę analizy rozwiązań technicznych realizowanych w budownictwie mieszkaniowym na podstawie kilkuset świadectw charakterystyki energetycznej budynków oraz projektowych charakterystyk energetycznych wykonanych dla próby 168 budynków certyfikowanych w ramach własnej działalności inżynierskiej. Analiza miała za zadanie wykazać istnienie oczekiwanych w ramach zaostrzających się wymagań technicznych kierunków zmian oraz ewentualnie wskazać na istnienie trendów wynikających z innych przyczyn. 


\section{Zakres i przedmiot badań}

Zakresem badań objęto 168 budynków obejmujących kilkaset stanowiących samodzielną całość techniczno-użytkową [2] lokali użytkowych. Budynki znajdują się w całej Polsce ze zdecydowanym wskazaniem województwa Dolnośląskiego oraz Wrocławia.

Analiz dokonano na podstawie:

- świadectw charakterystyki energetycznej sporządzonych dla zrealizowanych i oddawanych do użytkowania budynków (125 budynków) - w skrócie SCHE

n projektowanych charakterystyk energetycznych budynków (43 projektowane budynki) - w skrócie CHE

W obydwóch grupach analizowano osobno budynki mieszkalne jednorodzinne oraz wielorodzinne.

- Ocenie poddano następujące parametry:

- uzyskany wskaźnik energii pierwotnej EP

- uzyskany wskaźnik energii końcowej EK

- współczynnik przenikania ciepła U dla ścian zewnętrznych

- współczynnik przenikania ciepła U dla dachów i stropodachów

- współczynnik przenikania ciepła Uw dla okien

- rodzaj stosowanej w budynku wentylacji

- rodzaj stosowanego w budynku źródła ciepła

Wszystkie obliczenia wykonano zgodnie z Rozporządzeniem Ministra Infrastruktury i Rozwoju w sprawie metodologii wyznaczania charakterystyki energetycznej budynku lub części budynku oraz świadectw charakterystyki energetycznej (Dz.U. poz. 376 z dn. 18 marca 2015 r.) [1] , Polskimi Normami oraz przepisami pokrewnymi.

\section{Trendy w popycie na świadectwa charakterystyki energetycznej}

Świadectwa charakterystyki energetycznej zgodnie z obowiązującymi przepisami powinny być przekazane przez sprzedawcę lub wynajmującego kupującemu lub wynajmującemu budynek lub lokal użytkowy. W praktyce, z powodu nieprecyzyjnych zapisów w ustawie o charakterystyce energetycznej budynków [2] obowiązek ten nie jest dotrzymywany a jego spełnienie jest uzależnione od roszczenia strony kupującej lub wynajmującej. Taki stan obowiązuje od 8 marca 2015 r. do kiedy inwestorzy po zakończeniu budowy mieli obowiązek sporządzić świadectwo charakterystyki energetycznej budynku.

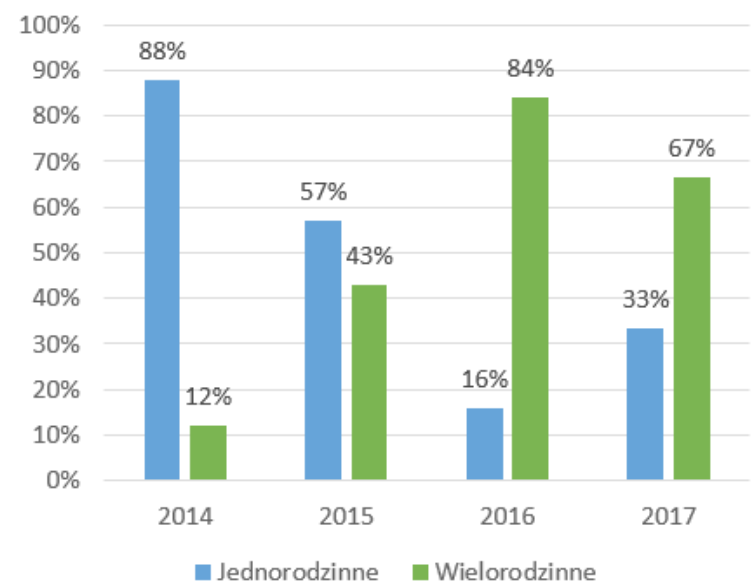

Ryc. 1. Procentowy udział w wykonanych SCHE dla budynków jednorodzinnych oraz wielorodzinnych

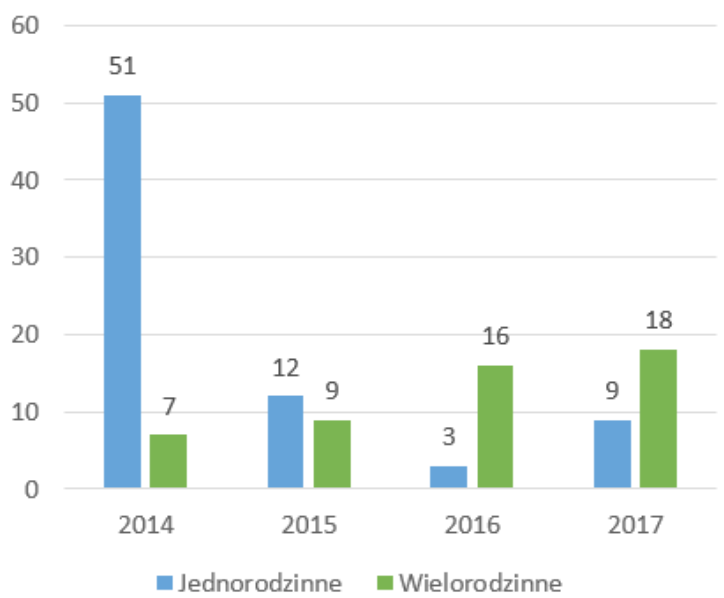

Ryc. 2. Ilościowy udział w wykonanych SCHE dla budynków jednorodzinnych oraz wielorodzinnych 
Z przeprowadzonej analizy wynika, że ilościowo oraz procentowo wzrasta liczba wykonywanych SCHE na rzecz budynków wielorodzinnych. Rośnie liczba deweloperów zainteresowanych posiadaniem SCHE, przekazywanie których podczas aktu sprzedaży stało się powszechne. Przeciwnie zaś maleje liczba wykonywanych SCHE dla domów jednorodzinnych - prywatni Inwestorzy nie są zainteresowani ich posiadaniem najprawdopodobniej w wyniku niskiego poziomu świadomości ekologicznej. Wyjątek stanowi oczywiście rok 2014 w których funkcjonował obowiązek wykonania SCHE dla każdego nowego budynku.

\section{Trendy w kształtowaniu się wartości EP}

Wskaźnik nieodnawialnej energii pierwotnej czyli ilość energii zawartej w kopalnych surowcach energetycznych [2], wyrażony w kWh/m rok, zgodnie z metodologią jego wyznaczania zależy głównie od źródła ciepła jakie zostało zastosowane w budynku. Niższe wartości mają źródła ciepła nie tylko z odnawialnych źródeł takich jak energia solarna czy geotermalna ale także ze źródeł nie uważanych za ekologiczne jak pelet czy drewno kominkowe. Z drugiej strony źródła energii oparte o prąd elektryczny a więc np. pompy ciepła, akumulacyjne grzejniki elektryczne charakteryzują się wyższymi wartościami współczynnika EP co prowadzi często do uzyskiwania wyników dla budynków niezgodnych z oczekiwaniami Inwestorów. Analizy pokazują stałą tendencję do zmniejszania się wartości EP dla nowoprojektowanych budynków (Ryc. 3), co jest rezultatem zmiennych wymagań Prawa Budowlanego, podczas gdy wartości EP dla budynków wybudowanych są na stałym poziomie (Ryc. 4) co potwierdza brak zrozumienia wśród Inwestorów dla środowiskowej opłacalności z otrzymania niskiej wartości EP.

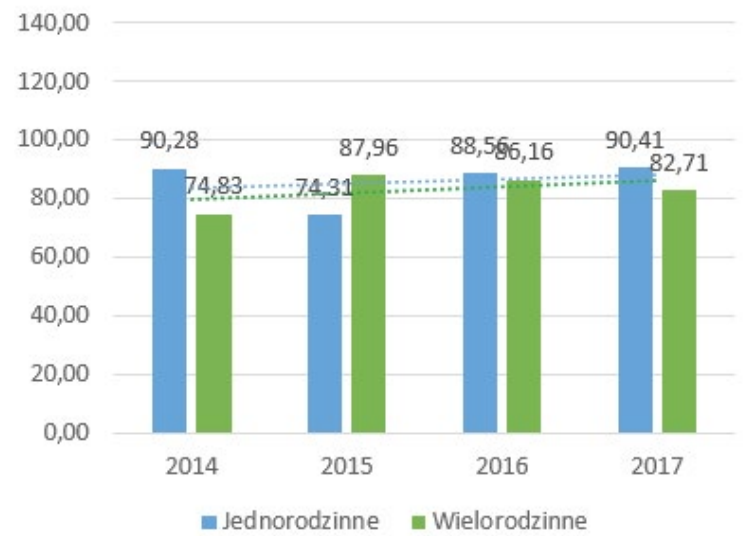

Ryc. 3. Wartości EP dla budynków oddawanych do użytkowania.

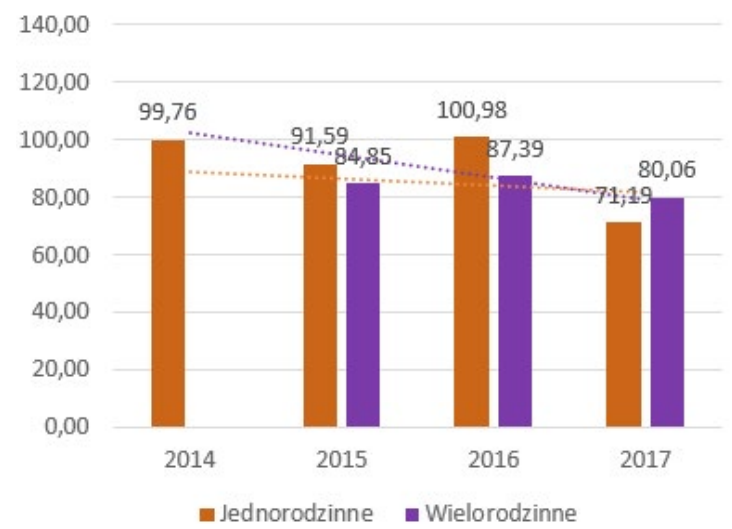

Ryc. 4. Wartości EP dla budynków projektowanych.

\section{Trendy w kształtowaniu się wartości EK}

Wskaźnik energii końcowej EK, wyrażony w postaci kWh/m²*rok określa ilość energii dostarczaną do budynku dla systemów technicznych niezbędną do ogrzewania, wentylacji, podgrzewania c.w.u. oraz zasilania urządzeń technicznych. Niższe wartości świadczą o dużej efektywności energetycznej urządzeń oraz decydują o kosztach opłat za energię w trakcie użytkowania budynku.

Przeprowadzone analizy wskazują, że w przypadku budynków budowanych wartość wskaźnika EK dla budynków jednorodzinnych nie zmienia się podczas gdy dla budynków wielorodzinnych na przestrzeni lat 2014-2017 spada, jednak przy uwzględnieniu ostatnich trzech lat wartość ta też się kształtuje na podobnym poziomie lub nawet spada (Ryc. 5).

W przypadku budynków projektowanych wartość EK znacznie maleje w czasie co wynika ze zmiennych wymagań prawa budowlanego (Ryc. 6). 


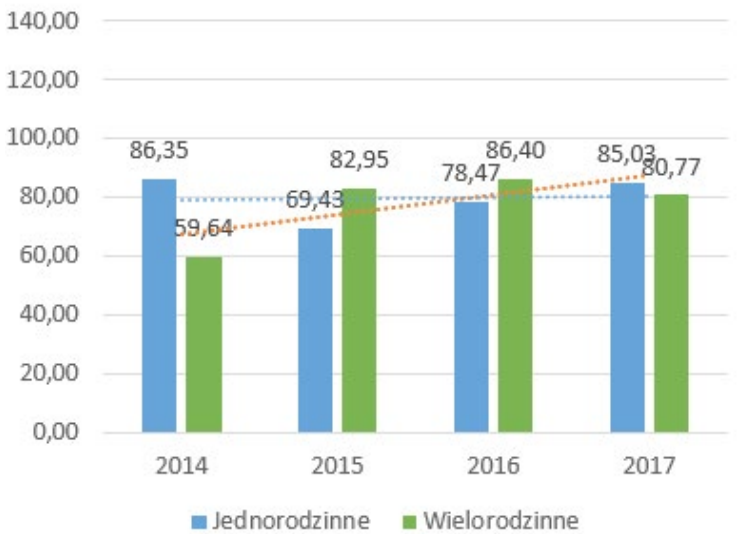

Ryc. 5. Wartości EK dla budynków oddawanych do użytkowania.

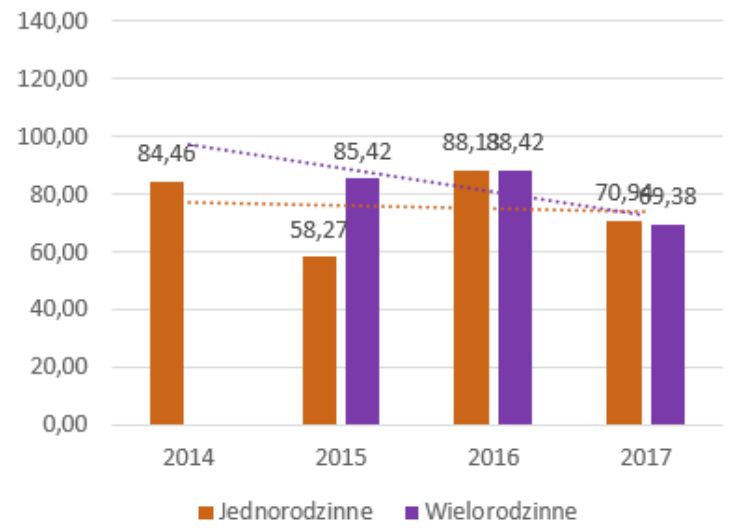

Ryc. 6. Wartości EK dla budynków projektowanych.

\section{Trendy w kształtowaniu się wartości U dla przegród zewnętrznych i stolarki okiennej}

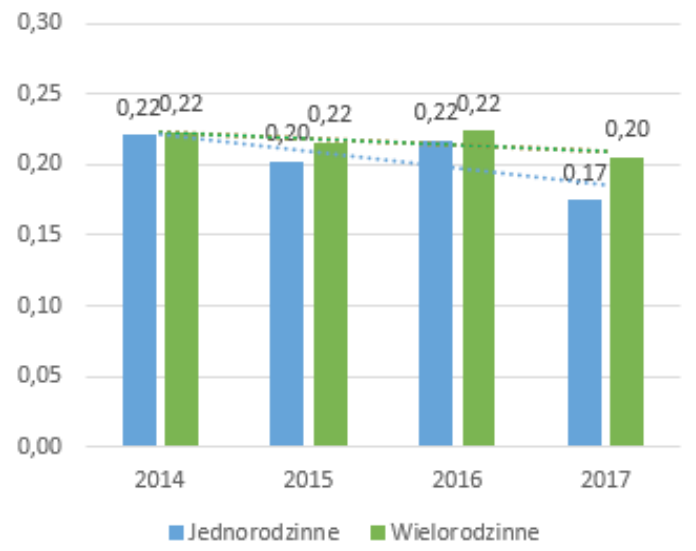

Ryc. 7. Wartości U dla ścian zewnętrznych dla budynków oddawanych do użytkowania.

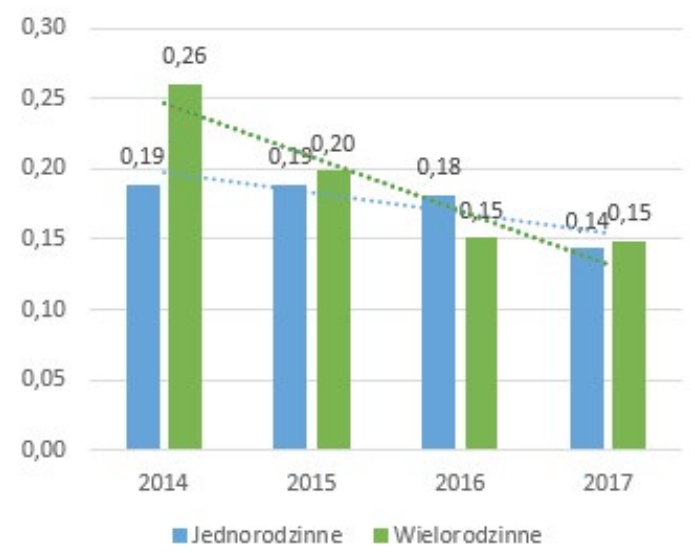

Ryc. 9. Wartości U dla dachu dla budynków oddawanych do użytkowania.

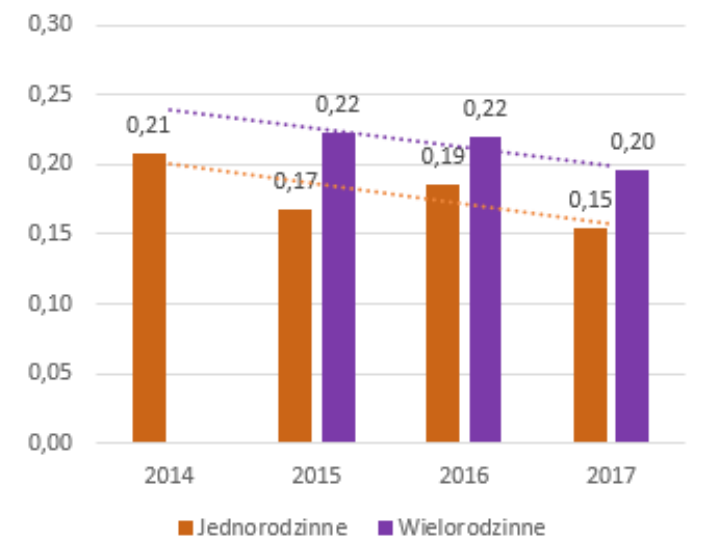

Ryc. 8. Wartości U dla ścian zewnętrznych dla budynków projektowanych.

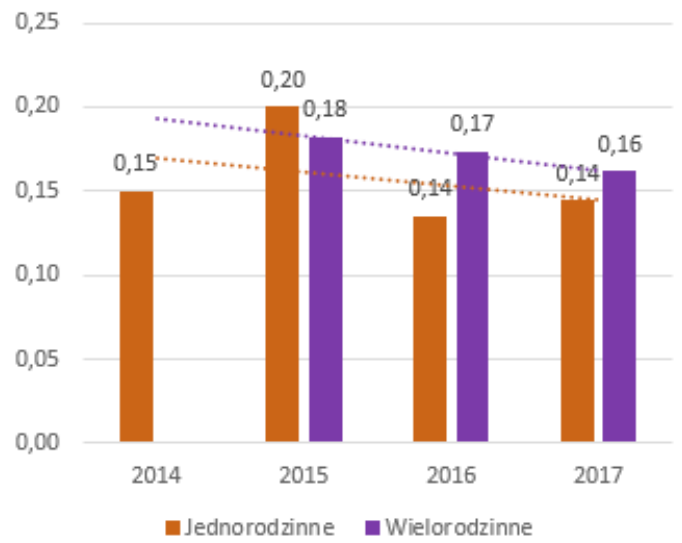

Ryc. 10. Wartości U dla dachu dla budynków projektowanych. 
Wartość wskaźnika Uw przenikalności cieplnej przegród zewnętrznych zależy od ich oporu cieplnego i odpowiada za małe straty energii cieplnej przez przenikanie przez przegrody. Wyniki przeprowadzanych analiz (Ryc. 7, $8,9,10,11,12)$ potwierdzają trend stopniowego obniżania wartości Uw, który można uzasadnić za powszechną opinia, że za energooszczędność domu odpowiadają w największym stopniu izolacje termiczne.

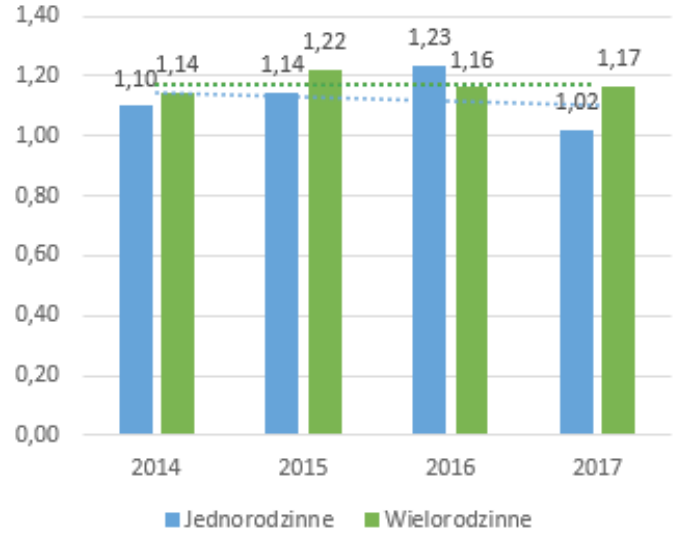

Ryc. 11. Wartości Uw dla okien dla budynków oddawanych do użytkowania.

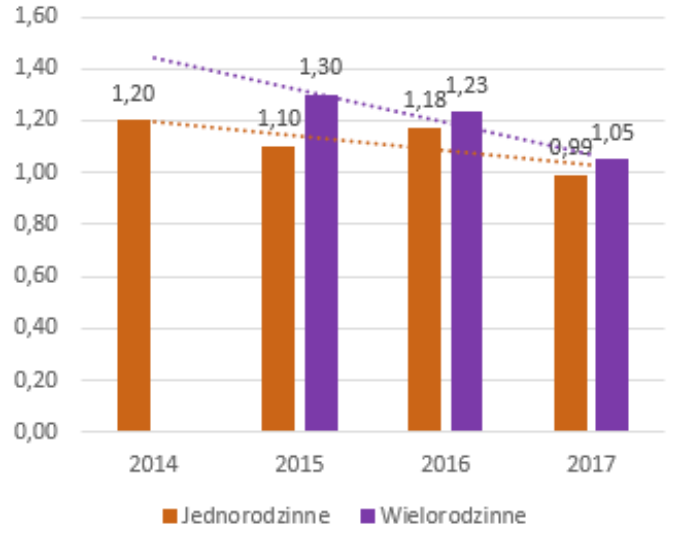

Ryc. 12. Wartości Uw dla okien dla budynków projektowanych.

\section{Trendy w stosowanych systemach technicznych wentylacji}

Wyróżniono cztery systemy wentylacji: grawitacyjną, wywiewną (hybrydową), nawiewno-wywiewną oraz nawiewno-wywiewną rekuperacją. Zastosowanie wentylacji grawitacyjnej skutkuje wysokimi wartościami EK oraz EP jednak jest rozwiązaniem tanim. Z drugiej strony zastosowanie wentylacji z odzyskiem ciepła jest rozwiązaniem efektywnym energetycznie ale drogim, co zniechęca inwestorów do jej stosowania.

W analizowanych przypadkach widać zdecydowaną niechęć Inwestorów, szczególnie prywatnych do stosowania innych rozwiązań niż wentylacja grawitacyjna (Ryc. 13). Wyraźny trend za to pokazują wyniki dla budownictwa wielorodzinnego (Ryc. 14) w których coraz częściej stosuje się wentylację hybrydową. Jest to związane niewielkim nakładem dodatkowych kosztów a wręcz z ich zmniejszeniem wspomaganym dodatkowo uzyskaną powierzchnią użytkową przeznaczoną do sprzedaży. Trend ten powtarza się też dla budynków projektowanych (Ryc. 15, 16).

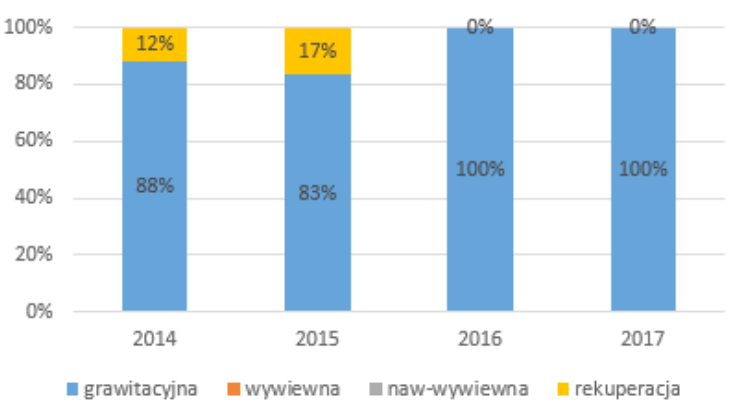

Ryc. 13. Rodzaje stosowanej wentylacji w budynkach jednorodzinnych oddawanych do użytkowania.

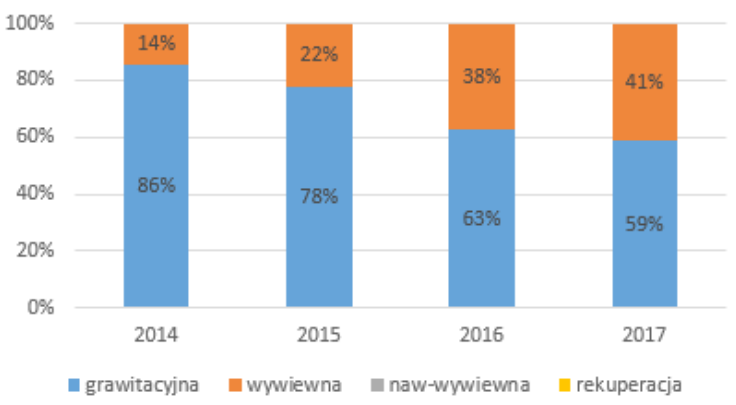

Ryc. 14. Rodzaje stosowanej wentylacji w budynkach wielorodzinnych oddawanych do użytkowania. 


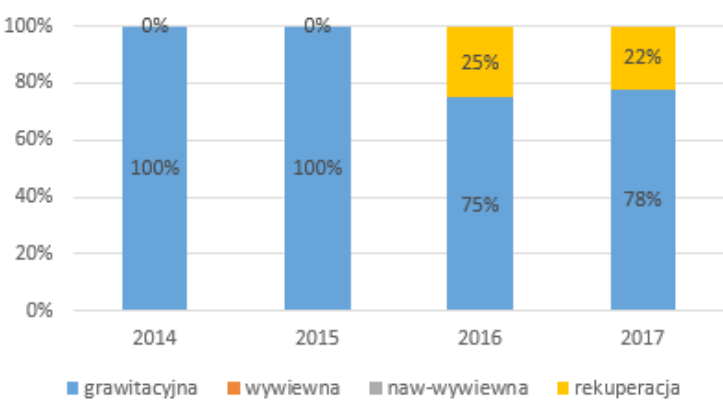

Ryc. 15. Rodzaje stosowanej wentylacji w budynkach jednorodzinnych oddawanych do użytkowania.

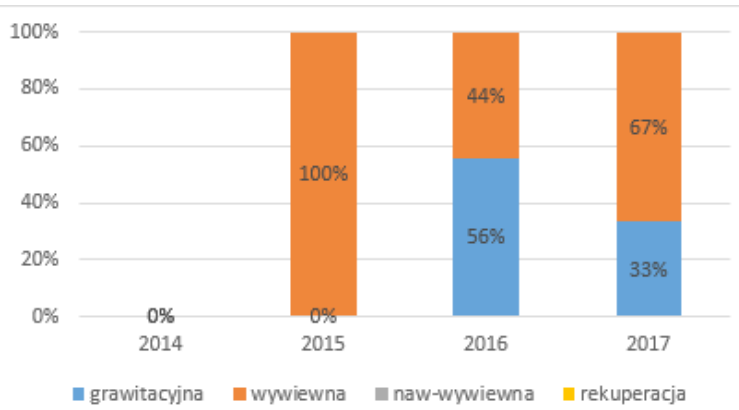

Ryc. 16. Rodzaje stosowanej wentylacji w projektowanych budynkach wielorodzinnych.

\section{Trendy w stosowanych systemach technicznych ogrzewania}

Wyróżniono siedem różnych źródeł ciepła: sieciowe, gazowe 1-funkcyjne, gazowe 2-funkcyjne, węglowe, olejowe, biomasę oraz pompę ciepła. Wybór danego systemu w dużym stopniu decyduje o wartości współczynników EK i EP ale może być też wyzwaniem dla budżetu Inwestora.

W przeprowadzonych analizach widać, że w przypadku budynków jednorodzinnych oddawanych do użytkowania przeważają kotły gazowe wypierające powoli kotły węglowe (Ryc. 17). W przypadku budynków wielorodzinnych dominuje ogrzewanie sieciowe lub w przypadku jego braku także ogrzewanie gazowe (Ryc. 18).

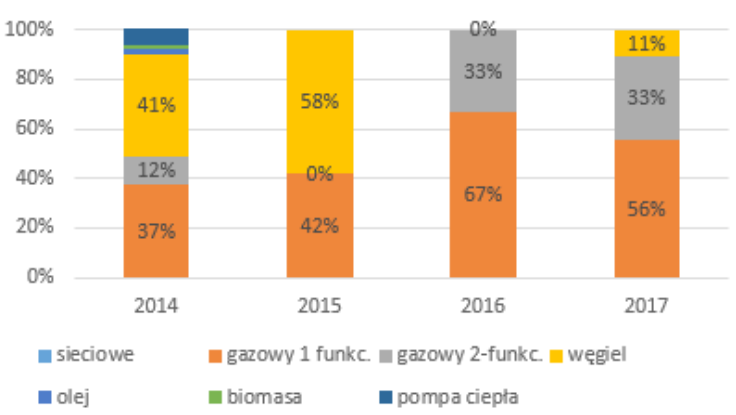

Ryc. 17. Rodzaje zastosowanego źródła ciepła w budynkach jednorodzinnych oddawanych do użytkowania.

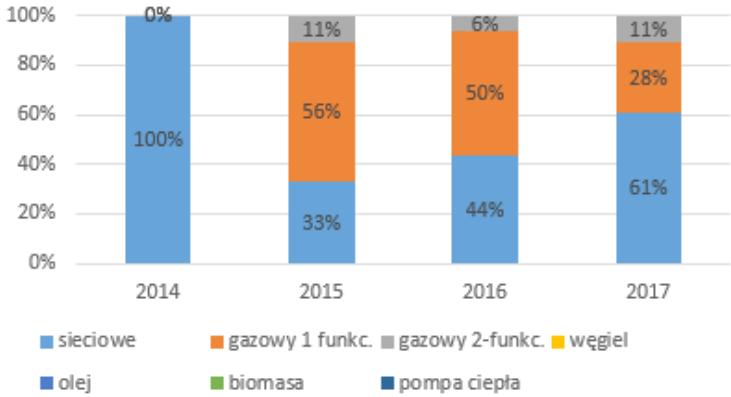

Ryc. 18. Rodzaje zastosowanego źródła ciepła w budynkach wielorodzinnych oddawanych do użytkowania.

W przypadku budynków projektowanych jednorodzinnych źródła ciepła ulegają dywersyfikacji (Ryc. 19), często na korzyść paliw odnawialnych, podczas gdy dla budynków wielorodzinnych dominuje ogrzewanie sieciowe oraz gazowe (Ryc. 20).

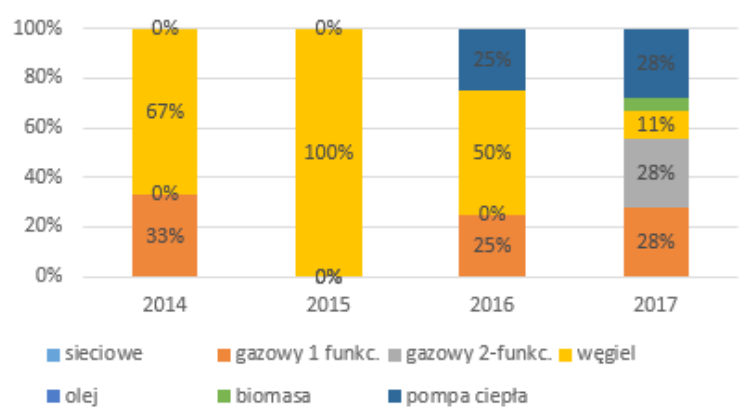

Ryc. 19. Rodzaje zastosowanego źródła ciepła w projektowanych budynkach jednorodzinnych.

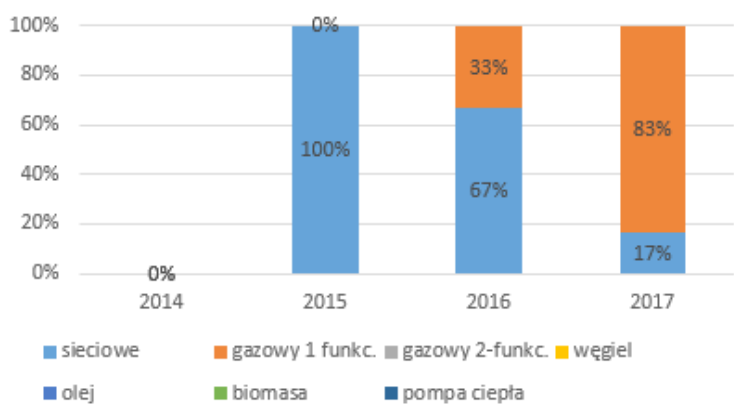

Ryc. 20. Rodzaje zastosowanego źródła ciepła w projektowanych budynkach wielorodzinnych. 


\title{
Podsumowanie
}

Przedstawione powyżej analizy wstępnie wskazują na istniejące, oczekiwane bądź nowe trendy w stosowaniu energooszczędnych lub ekologicznych rozwiązań w budownictwie mieszkalnym. Można przyjąć wstępną tezę o korelacji pomiędzy aktywnością inwestorów w zakresie stosowania powyższych technologii a ich wiedzą techniczną bądź świadomością ekologiczną. Prowadzi to do wniosku o konieczności podejmowania przez osoby kompetentne lub instytucje zintensyfikowanych działań edukacyjnych w zakresie budownictwa energooszczędnego i korzyści środowiskowych.

\section{Piśmiennictwo}

[1] Rozporządzeni Ministra Infrastruktury i Rozwoju w sprawie metodologii wyznaczania charakterystyki energetycznej budynku lub części budynku oraz świadectw charakterystyki energetycznej (Dz. U. poz. 376 z dn. 18 marca 2015 r.)

[2] Ustawa o charakterystyce energetycznej budynków (Dz.U. poz. 1200 z 2014 r.)

\section{Optimization of barrel vault surfaces using energetic potential method}

\begin{abstract}
The energy certification, introduced in 2009, enables interested parties or organizations to analyze the data developed during the preparation of energy performance certificates or the proposed energy performance of a building. Through comparatitive analysis, trends can be described using the criteria for shaping them as needed.

The author has made selected analyzes focusing on residential housing in the division of single family and multi-family housing. Obtained results indicate the existing and expected trends related to the reduction of fossil fuel consumption but also show their slow pace and in some cases even no change. The conclusions drawn show the reasons for a certain rate of change, enabling them to undertake actions supporting certain tendencies or initiating them.

As part of this work, the author analyzed selected indicators on the basis of their 168 energy certificates of residential buildings in 2014-2017.
\end{abstract}

Keywords: Energy-saving construction, energy certification, ecology, sustainable development. 